\title{
SEX RATIO, FECUNDITY AND MORPHOMETRY OF THE EGGS OF FRESHWATER PRAWN Macrobrachium americanum (BATE, 1868) IN THE PETATLÁN RIVER, SINALOA, MEXICO
}

\author{
Genaro Diarte-Plata ${ }^{1}$, Ruth Escamilla-Montes ${ }^{1 *}$, Salvador Granados-Alcantar ${ }^{2}$, Antonio Luna-González ${ }^{1}$
}

${ }^{1}$ Instituto Politécnico Nacional, CIIDIR- Unidad Sinaloa. Departamento de Acuacultura. Blvd. Juan de Dios Batiz Paredes \# 250, Col. San Joachin, A.P. 280. C.P. 81101. Guasave, Sinaloa, México

${ }^{2}$ Universidad Autónoma de Occidente, Unidad Los Mochis. Departamento de Biología. Blvd. Macario Gaxiola s/n. Carretera internacional, C.P. 81223. Los Mochis, Ahome, Sinaloa, México

*Corresponding Author: ruthescamilla25@hotmail.com

\section{ARTICLE INFO}

Received: 12 July 2020

Accepted: 1 December 2020

\begin{abstract}
Macrobrachium americanum has a high commercial value with good fishing and cultivation possibilities in Mexico. Currently there is little information on reproductive aspects so the present work analyzed the sex ratio, fecundity and morphometry of the eggs of $M$. americanum in the Petatlán River, Sinaloa, Mexico. A total of 31 ovigerous females were captured. The sex ratio was $0.39 \mathrm{~F}: 1 \mathrm{M}$. The partial fecundity (Pf) varied from 34, 554 to 342, 372 eggs (128, $246 \pm$ 12, 306 eggs, average $\mathrm{Pf})$. The relationships between body and length-fecundity $\left(R^{2}=0.5546\right)$, cephalothorax and length-fecundity $\left(R^{2}=0.4995\right)$ were adjusted to a linear model, and the total weight-fecundity to a potential model $\left(R^{2}=0.5013\right)$. The average relative fecundity was 37, $132 \pm 5,162$ eggs/g. A total of 7 stages of embryonic development were observed. In the first stages, the egg presents a spherical form and in the latter an ovoid shape. Maximum egg diameter values are presented in stages VII, VI and VIII. Stage II provided the largest number of eggs $(1,013,073$ eggs). It is essential to optimize the exploitation of the population of $M$. americanum present in the Petatlán River through the creation of scientific bases for the sustainability of the fishery.
\end{abstract}

Diarte-Plata, G., Escamilla-Montes, R., Granados-Alcantar, S., LunaGonzález, A. (2021): Sex ratio, fecundity and morphometry of the eggs of freshwater prawn Macrobrachium americanum (Bate, 1868) in the Petatlán River, Sinaloa, Mexico. Croatian Journal of Fisheries, 79, 1-14. DOI: $10.2478 /$ cjf-2021-0001. 


\section{INTRODUCTION}

Freshwater prawns of the genus Macrobrachium are distributed in tropical and subtropical areas. There are more than 291 species and subspecies registered by the Integrated Taxonomic Information System (SIIT), of which 48 are found in Latin America along the Pacific coast, such as Macrobrachium hancocki, $M$. tenellum and $M$. americanum (Guzmán, 1987; Álvarez-Ruiz et al., 1996; Jayachandran, 2001; SIIT, 2013).

M. americanum commonly known as freshwater prawn is distributed on the Pacific coast of America, from Cedros Island, Baja California, Mexico to Paita, Peru (Chirichigno et al., 1982; Hernández et al., 2007). They are freshwater organisms, however, their life cycle ends when the ovigerous females reach the estuaries to spawn in brackish waters (Mossolin and Bueno, 2002). The life cycle has two important aspects: a larval development that comprises more than twelve stages and that, in at least one of these, saline water is needed to survive. Females can spawn many times a year and produce thousands of eggs in each spawn which are carried under the abdomen during incubation (García-Guerrero and Hendrickx, 2009), whose duration depends on the temperature of the water (García-Guerrero, 2010). Females feed, reproduce and spawn in freshwater but larvae must be in saline water at the beginning of their development. In some species the eggs are incubated and the larvae are released upstream, being transported drifting towards the sea (estuarine zone) along the riverbed. In other species, females migrate downstream, bringing the mass of eggs closer to the coastal bays or estuaries where they hatch. The larvae are planktonic and once they have been transformed and grown to juvenile stages, they begin to migrate from the coast to the freshwater high areas, thereby contributing to the flow of energy converted into biomass, along the different habitats through which they pass (Bauer, 2011a, 2011b).

This species of fishing interest is exploited through artisanal fishing; it is caught especially with atarrayas (circular nets) and traps (Diarte-Plata et al., 2010; 2012). Despite being exploited on a rather small scale, it has a high demand and commercial value in Mexico, Guatemala and El Salvador (Ponce-Palafox et al., 2002; EspinosaChaurand et al., 2011).

The method of capturing $M$. americanum by the residents of the Petatlán River (Sinaloa River) is to take advantage of the increase in the riverbed during the rainy season, to carry out the artisanal fishery by means of nasa traps, which can be extended throughout the year (Diarte-Plata et al., 2012).

The ecological and economic benefits of the aquaculture of this species are emphasized in the importance of the proper management of natural populations and crop systems, based on the knowledge of the biology and ecology, as well as the development of sustainable biotechnologies. M. americanum is a species with a great potential for the commercial farming due to its large size, market and economic value. Information about the reproductive biology of prawns is an important tool to determine if this species is a suitable candidate for aquaculture, and necessary for the development of appropriate management strategies in cultures (Mossolin and Bueno, 2002).

Knowledge of the fecundity of a species is essential to determine its reproductive capacity, the minimum number of adult organisms needed to maintain recruitment, to estimate the population size and to evaluate its potential for aquaculture (Da Silva et al., 2004; Parra-Medina et al., 2010). In freshwater prawn, fecundity is established as the number of eggs produced at a reproductive period and reflects the reproductive capacity of each female (Parra et al., 2010). However, other authors define it as the number of eggs laid for hatching and adhered to the female pleopods (Da Silva et al., 2004). Despite the biological and economic importance of $M$. americanum, information on this species is scarce and not so recent, making it difficult to establish a scientific-technical picture (Granados, 1980; Ponce-Palafox et al., 2002; De los Santos-Romero et al., 2006; Diarte-Plata et al., 2010; Espinosa-Chaurand, et al., 2011; Diarte-Plata et al., 2012). Therefore, the objective of this paper is to contribute to the knowledge on the sex ratio, fecundity, morphology and morphometry of the eggs of $M$. americanum, which is essential to optimize the sustainable exploitation of the population of $M$. americanum in the Petatlán River, Sinaloa, Mexico.

\section{MATERIAL AND METHODS}

Sampling of $M$. americanum was performed on a monthly basis between September 2014 and November 2015 on the banks of the Petatlán River located near the town of El Opochi (middle portion), municipality of Sinaloa de Leyva, state of Sinaloa, Mexico ( $25^{\circ} 39^{\prime} 54^{\prime \prime} \mathrm{N}$ and $107^{\circ} 27^{\prime}$ $\left.56^{\prime \prime} \mathrm{W}\right)$. The sampling sites were established considering the areas and the method of capture developed by fishermen engaged in the exploitation of the freshwater shrimp in the middle portion of the Petatlán River. A sampling transect was established with a length of 1000 $\mathrm{m}$, collecting organisms with 10 nasa-type cylindrical traps (1 inch, mesh light), placed at $100 \mathrm{~m}$ between traps which were installed at sunset (19:00 h), being checked the following morning (6:00 h) (Goodyear et al., 1976; Ponce-Palafox et al., 2002; Diarte-Plata et al., 2012). For each organism at the sampling site, the sex, presence or absence of eggs in incubation were inspected. The incidence of ovigerous females was recorded and they were stored in $10 \%$ formaldehyde solution in pre-labelled $1000 \mathrm{ml}$ plastic flasks for laboratory processing. 


\section{Sex ratio}

In the laboratory, the total or body length (distal part of the rostrum to the distal part of the telson) $(\mathrm{TL})(\mathrm{mm})$ and the length of the cephalothorax (distal part of the rostrum to the posterior middle part of the cephalothorax) (CL) $(\mathrm{mm})$ were recorded with an analogous Vernier caliper (Mitutoyo ${ }^{\circledR}$ ) with an accuracy of $0.01 \mathrm{~mm}$, and in the case of females the total weight without the ovigerous mass (TW) (g) with a digital scale $\left(\right.$ Ohaus $\left.^{\circledR}\right)$, with an accuracy of $0.01 \mathrm{~g}$. The overall sex ratio was determined by month and by size range.

\section{Fecundity}

Of each ovigerous female, the egg mass was removed and rinsed with fresh water and weighed (WOM) in order to posteriorly remove the villi from the pleopods. The estimation of partial fecundity (Pf) was made by using the gravimetric method; three sub-samples of $0.1 \mathrm{~g}$ of each ovigerous mass were weighed in an analytical scale, with an accuracy of $0.0001 \mathrm{~g}$ (Sartorius ${ }^{\circledR}$ ). The eggs in each subsample were stored in $1.5 \mathrm{ml}$ (Eppendorf ${ }^{\circledR}$ ) plastic tubes with $10 \%$ neutral formalin for counting. The eggs were placed in a Petri box with a grid bottom (millimeter sheet), with $2 \mathrm{ml}$ of a mixture of ethanol-glycerin $\mathrm{v} / \mathrm{v}$. Under a stereoscopic microscope (Carl Zeiss ${ }^{\circledR}$ ) at $4 x$, the eggs contained in 20 frames taken at random were counted; the result was used to determine the total number of eggs contained in the sample. For each female, the counted eggs were extrapolated to the total weight of the ovigerous mass to obtain a partial fecundity estimate (Pf) (Choy, 1985, Escamilla-Montes et al., 2013). Partial fecundity was determined using the equation by PinedaBarrera et al. (1975) (Equation 1):

$$
F=(G * N(X)) / g
$$

where $F=$ partial fecundity in number of eggs, $G=$ total weight of the ovigerous mass $(g), N(X)=$ average number of eggs in the three sub-samples, $g$ = average weight of the three sub-samples (g).

To analyze the relationship between partial fecundity (Pf), total length (TL) and cephalothorax length (CL), the data were adjusted to the following linear model: $Y=a$ $+b x$, where $a$ is the intercept, $b$ is the slope of the line and $\mathrm{x}$ is the morphometric variable to evaluate, while for the relationship between partial fecundity (Pf) and total weight (TW), the following potential model was used (Equation 2):

$$
Y=a X^{b}
$$

where $a$ is the intercept, $b$ is the slope of the line and $x$ is the morphometric variable to evaluate.

The relative fecundity (Rf) was obtained with the relationship between the number of eggs per gram of total weight for each ovigerous female (Lorh, 1999; Velázquez-Abunader et al., 2010).

\section{Egg development}

The embryonic stage of development of the eggs was identified in each ovigerous mass analyzed, based on the observations of yolk coverage and growth of body structures reported for Palaemonida (Yávar and Dupré, 2007; García-Guerrero and Hendrickx, 2009).

\section{Egg morphometry}

A total of 30 eggs were extracted from each subsample $(n=90)$ used for the determination of fecundity to identify the stages of embryonic development. The criteria by García-Guerrero and Hendrickx (2009) were considered for the freshwater prawn M. americanum. For morphometry, the major and minor axes (90 eggs per stage) were measured with a stereoscopic microscope with a graduated lens (Stemi 2000-Carl Zeiss ${ }^{\circledR}$ ), with an accuracy of $0.05 \mu \mathrm{m}$. The relationship between the egg morphometry with the partial and relative fecundity was established by linear regression (Escamilla-Montes et al., 2013).

\section{Statistical analyses}

In order to establish the differences in biometric data and the relationships between Pf-TL, Pf-CL and Pf-TW, a one way ANOVA was used. A Tukey test was used to find which groups showed differences. For the sex ratio, a Ji-square statistics $\left(\chi^{2}\right)$ was used, establishing a sex ratio of $1 \mathrm{~F}: 1 \mathrm{M}$. The observed value was compared with the theoretical value of $\chi^{2}$ with an alpha of 0.05 . Statistical packages of Excel $^{\circledR}$ and Statistica ${ }^{\circledR} 7.0$ were used (Zar, 2010).

\section{RESULTS}

\section{Sex ratio}

A total of 593 organisms were captured: 427 males (72\%) and 166 females (28\%) of which 31 were ovigerous. The distribution of size frequencies showed a bimodal behavior for both sexes, with the majority measuring between 140 to $180 \mathrm{~mm}$ of total length, with a minimum size of $85 \mathrm{~mm}$ and a maximum of $230 \mathrm{~mm}$ and an average of $14.82 \pm 0.09 \mathrm{~cm}$ in TL (Fig. 1).

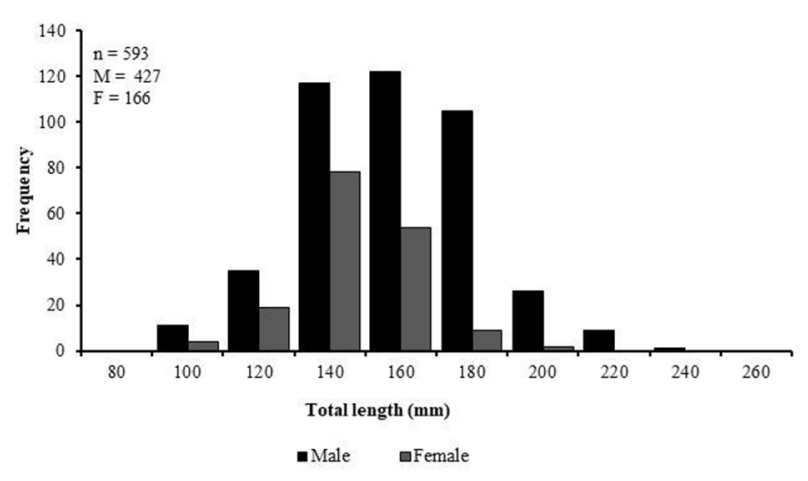

Fig 1. Sex ratio by size interval of Macrobrachium americanum 
The sex ratio was $0.39 \mathrm{~F}: 1 \mathrm{M}$, which differed significantly from 1F: $1 \mathrm{M}\left(\chi_{(0.05,14)}^{2}=23.68 ; P<0.05\right)$, with significant differences in the months of November $\left(\chi^{2}=14 ; P<0.05\right)$, December $2014\left(\chi^{2}=4.17 ; P<0.05\right)$ and January $\left(\chi^{2}=\right.$ 17.64; $P<0.05)$, March $\left(\chi^{2}=57.79 ; P<0.05\right)$ and between August $\left(\chi^{2}=26.13 ; P<0.05\right)$ and November $2015\left(\chi^{2}=\right.$ 7.75; $P<0.05)$ (Fig. 2).

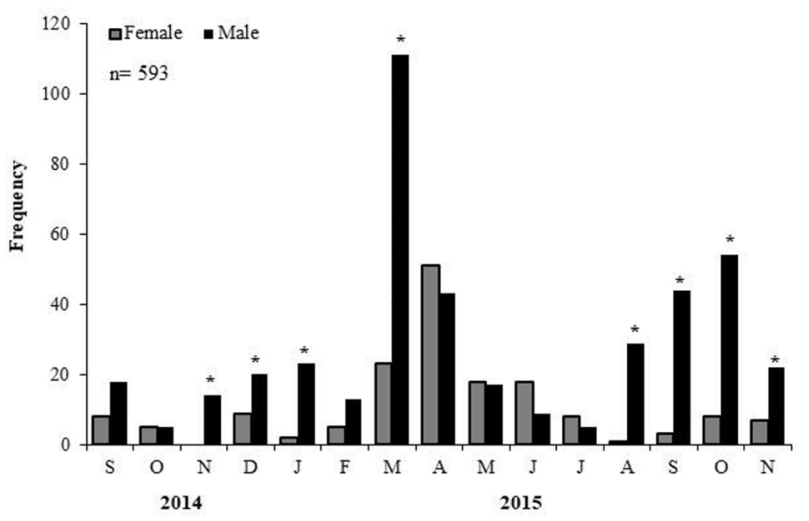

Fig 2. Sex ratio per month in M. americanum. $\left({ }^{*}\right)$ Indicate significant differences

The total incidence of ovigerous females in the capture was 31 organisms. Females were collected in September and October 2014 and between April and October 2015, with a peak in July 2015 (9 females) (Fig. 3). Total length (TL) of females of $M$. americanum ranged from 60 to 85 $\mathrm{mm}$ with an average of $153.7 \pm 13.1$, and a total weight of $72.38 \pm 3.65 \mathrm{~g}$.

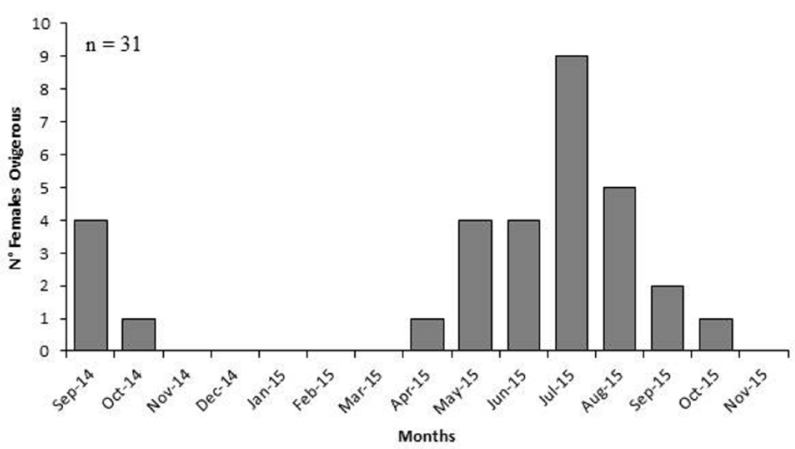

Fig 3. Incidence of ovigerous females (number of females) of Macrobrachium americanum

\section{Fecundity}

Average partial fecundity (Pf) was 128, $246 \pm 12,306$ eggs (mean \pm standard error) with a minimum value of 34 , 554 and a maximum of 342,372 eggs. Females with 130 $\mathrm{mm}$ of TL showed average partial fecundities of 62,678 eggs, whereas bigger females of $180 \mathrm{~mm}$ in TL showed an average $\mathrm{Pf}$ of 342,372 eggs. The difference between the total length and the number of eggs was significant $\left(F_{(20,10)}\right.$ =3.1484; $P=0.03309$ ). Average relative fecundity (Rf) for M. americanum was $37,132 \pm 5,162$ eggs/g (Table 1 ).
For the relationship Pf-TL and $\mathrm{Pf}-\mathrm{CL}$, the data were adjusted to a linear regression model $(\mathrm{Pf}=3771.7 \mathrm{TL}-$ 454804, $R^{2}=0.5505$ and $P f=7059.1 \mathrm{LC}-358711, R^{2}=$ 0.4969 , respectively) (Fig. $4 \mathrm{a}$ and b), whereas the relationship Pf-TW showed a coefficient of determination of $R^{2}=0.5011$ with a potential regression type model $P f=$ $321.69 \mathrm{PT}^{1.3724}$ (Fig. 4 c), indicating that between $50 \%$ and $55 \%$ of the fecundity variation is explained by the total length and total weight, respectively.

The relationships between Rf-TL, Rf-CL and Rf-TW were adjusted to linear type models, with low significant coefficients of determination (Fig. $5 \mathrm{a}, \mathrm{b}$ and c). The highest coefficient of determination was for the relationship Rf-TL with an $R^{2}=0.0065$ (Fig. 5a), and the lowest for Rf-TW with an $R^{2}=0.0003$ (Fig. 5c).

\section{Egg development}

A total of 7 stages of embryonic development were observed for M. americanum which are described below: Stage I. Egg moderately round without distinction of poles for being one of the first stages. The homogeneous granular vitelum comprises $90-100 \%$ of the volume of the egg. Average diameter $500 \mu \mathrm{m}$, with an interval from 460 to $540 \mu \mathrm{m}$ (1-2 embryonic development days) (Fig. 6A).

Stage II. The vitelum is observed towards a pole (vegetal), the vitelum covers $80-90 \%$ of the volume of the egg; both poles present, animal and vegetal. Average diameter 520 $\mu \mathrm{m}$ with an interval from 480 to $560 \mu \mathrm{m}$ (3-4 embryonic development days) (Fig. 6B).

Stage III. The shape of the egg tends to be ovoid, appearance of lateral ocular lines, vitelum occupying $70-80 \%$ of the volume of the egg. Average diameter 570 $\mu \mathrm{m}$ with an interval from 520 to $620 \mu \mathrm{m}$ (5-6 embryonic development days) (Fig. 6C).

Stage IV. Ocular spots in the egg are more intense than in stage 4 and are located towards the ends. There is a reduction of vitelum by $60-70 \%$ of egg volume. Average diameter $610 \mu \mathrm{m}$, with an interval from 560 to $660 \mu \mathrm{m}$ (7-8 embryonic development days) (Fig. 6D).

Stage $V$. The egg shows a round ocular stain, less amount of vitelum with $50-60 \%$ of the volume of the egg; there is a body segment from the organism. Average diameter 630 $\mu \mathrm{m}$ with an interval from 560 to $700 \mu \mathrm{m}$ (9-10 embryonic development days) (Fig. 6E).

Stage VI. The shape of the egg is elongated (ovoid), body of the organism more visible, the ocular stain more round than in stage $\mathrm{VI}$, with a more forward position, much reduced vitelum with $40-50 \%$ of egg volume. Average diameter $640 \mu \mathrm{m}$ with a range from 580 to $700 \mu \mathrm{m}$ (11-12 embryonic development days) (Fig. 6F).

Stage VII. Average diameter $650 \mu \mathrm{m}$, with an interval from 580 to $720 \mu \mathrm{m}$, most notable presence of the organism, frontal eyes, oval egg, presence of segments and some appendages of the body well-defined, vitelum, with 30$40 \%$ of the egg volume, stage prior to hatching (13-14 embryonic development days) (Fig. 6G). 
Table 1. Detailed results of stage of embryonic development phase (SEDP), total length (TL), cephalothorax length (CL), total weight (TW), weight of the ovigerous mass (WOM), average number of eggs in $0.1 \mathrm{~g}$ (ANE), partial fecundity (Pf) and relative fecundity (Rf) of the ovigerous females of $M$. americanum

\begin{tabular}{|c|c|c|c|c|c|c|c|c|c|}
\hline Organism & $\begin{array}{c}\text { Month of } \\
\text { capture }\end{array}$ & SEDP & $\begin{array}{c}\mathrm{TL} \\
(\mathrm{mm})\end{array}$ & $\begin{array}{c}\mathrm{CL} \\
(\mathrm{mm})\end{array}$ & $\begin{array}{l}\text { TW } \\
\text { (g) }\end{array}$ & $\begin{array}{c}\text { WOM } \\
\text { (g) }\end{array}$ & ANE & $\begin{array}{c}\text { Relative } \\
\text { fecundity (Rf) }\end{array}$ & $\begin{array}{c}\text { Partial } \\
\text { fecundity (Pf) }\end{array}$ \\
\hline 1 & Sep 2014 & IV & 148 & 68 & 78.5 & 2.3 & 1,579 & 14,948 & 36,547 \\
\hline 2 & Sep 2014 & V & 155 & 63 & 72 & 5.1 & 1,130 & 10,996 & 68,340 \\
\hline 3 & Sep 2014 & IV & 162 & 74 & 92.8 & 19.2 & 1,332 & 12,728 & 263,232 \\
\hline 4 & Sep 2014 & V & 163 & 71 & 86.5 & 13.1 & 1,261 & 11,680 & 167,811 \\
\hline 1 & Oct 2014 & III & 140 & 60 & 52.8 & 5 & 1,030 & 9,941 & 48,850 \\
\hline 1 & Apr 2015 & II & 135 & 60 & 45.5 & 5.9 & 1,358 & 13,037 & 83,190 \\
\hline 1 & May 2015 & II & 131 & 61 & 43.7 & 6.8 & 1,204 & 11,270 & 80,444 \\
\hline 2 & May 2015 & IV & 132 & 60 & 41.7 & 4.7 & 1,368 & 13,467 & 64,907 \\
\hline 3 & May 2015 & III & 150 & 63 & 60.5 & 6.6 & 1,574 & 15,597 & 103,884 \\
\hline 4 & May 2015 & III & 155 & 61 & 60.7 & 10.1 & 1,074 & 10,253 & 128,068 \\
\hline 1 & Jun 2015 & II & 148 & 67 & 59.6 & 4.9 & 1,591 & 15,510 & 79,037 \\
\hline 2 & Jun 2015 & I & 148 & 67 & 57.7 & 5.7 & 1,616 & 15,508 & 94,734 \\
\hline 3 & Jun 2015 & I & 150 & 65 & 72.1 & 12.3 & 1,589 & 15,217 & 193,971 \\
\hline 4 & Jun 2015 & I & 165 & 80 & 117.7 & 27.7 & 1,225 & 11,575 & 320,489 \\
\hline 1 & Jul 2015 & II & 142 & 64 & 50.9 & 5.1 & 1.258 & 12,423 & 64,413 \\
\hline 2 & Jul 2015 & II & 145 & 73 & 78.9 & 8.8 & 1,301 & 12,649 & 113,080 \\
\hline 3 & Jul 2015 & II & 150 & 64 & 59.8 & 6.7 & 1,260 & 12,134 & 80,668 \\
\hline 4 & Jul 2015 & II & 152 & 75 & 56.7 & 6.7 & 753 & 7,785 & 70,752 \\
\hline 5 & Jul 2015 & II & 153 & 70 & 75.9 & 10.2 & 1,543 & 14,712 & 156,672 \\
\hline 6 & Jul 2015 & II & 160 & 71 & 89.7 & 11.1 & 1,305 & 12,574 & 134,865 \\
\hline 7 & Jul 2015 & II & 165 & 74 & 98.5 & 14.2 & 986 & 9,543 & 149,952 \\
\hline 8 & Jul 2015 & IV & 167 & 82 & 112.7 & 17.5 & 1,286 & 12.745 & 221,200 \\
\hline 9 & Jul 2015 & IV & 170 & 76 & 95.3 & 13.2 & 1234 & 11,704 & 167,418 \\
\hline 1 & Aug 2015 & IV & 148 & 66 & 62.8 & 9.2 & 1,469 & 14,110 & 139,840 \\
\hline 2 & Aug 2015 & IV & 160 & 76 & 89.5 & 14.2 & 1,471 & 14,317 & 208,740 \\
\hline 3 & Aug 2015 & IV & 162 & 66 & 73.5 & 11.9 & 1,360 & 13,114 & 162,554 \\
\hline 4 & Aug 2015 & VII & 164 & 70 & 69.7 & 10.2 & 796 & 7,778 & 74,358 \\
\hline 5 & Aug 2015 & $\mathrm{VI}$ & 170 & 71 & 74.9 & 12.4 & 1,202 & 11,953 & 131,936 \\
\hline 1 & Sep 2015 & III & 130 & 58 & 52.2 & 5.9 & 1,068 & 10,163 & 64,900 \\
\hline 2 & Sep 2015 & I & 175 & 82 & 104.7 & 14.3 & 1,551 & 14,741 & 210,782 \\
\hline 1 & Oct 2015 & I & 150 & 66 & 56.4 & 9.4 & 1,596 & 15,451 & 127,558 \\
\hline
\end{tabular}



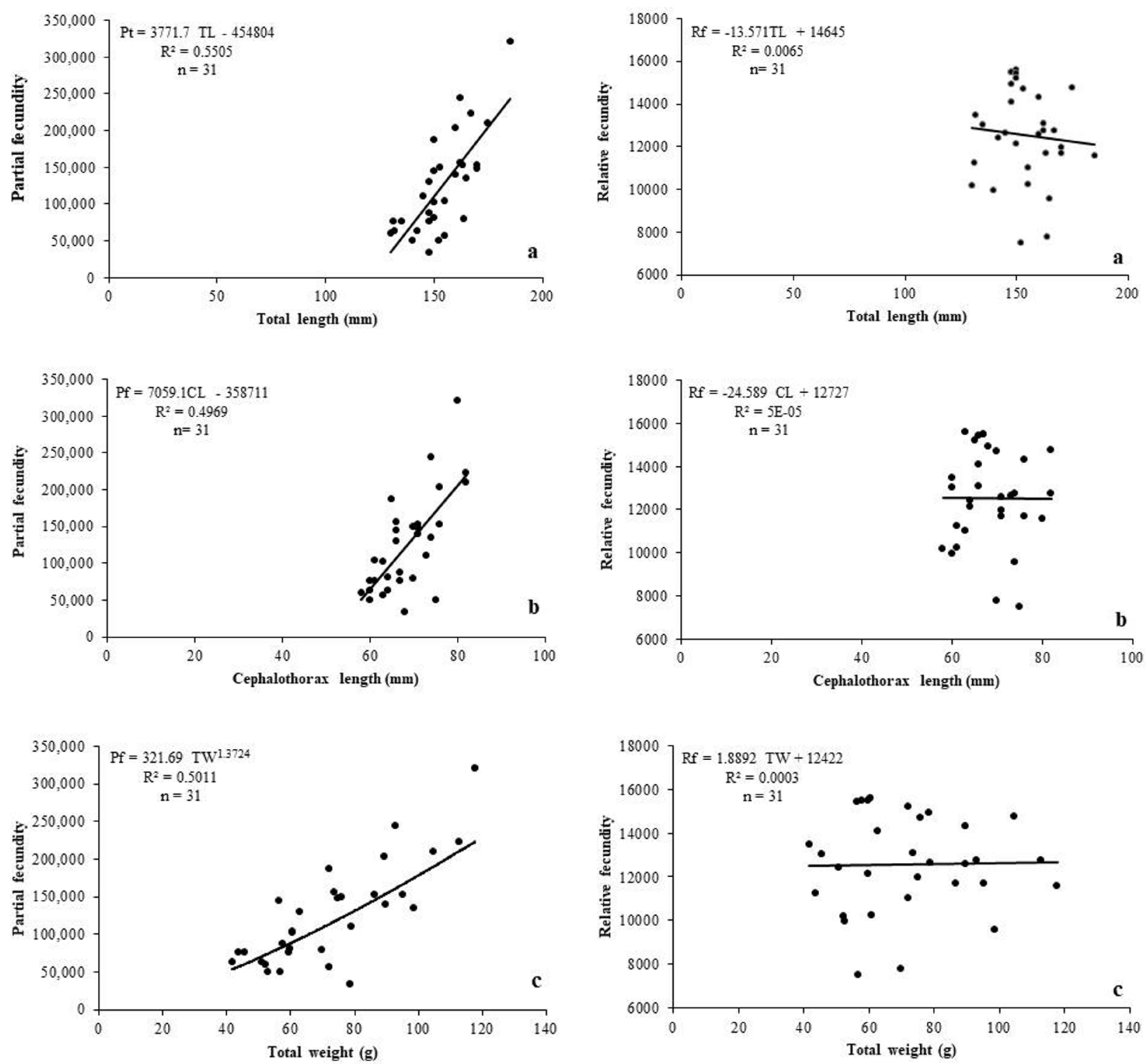

Fig 4. Relationship of partial fecundity with total length (a), length of the cephalothorax (b) and total weight (c) of females of Macrobrachium americanum

\section{Egg morphometry}

In relation to the morphometric characteristics of the eggs, the first stages presented a spherical form, while in the last stages the form in the eggs is ovoid or ellipsoidal. At different stages of embryonic development, maximum egg diameter values were presented in stage VII $(0.313 \pm$ $0.0192 \mu \mathrm{m})$, stage VI $(0.306 \pm 0.0147 \mu \mathrm{m})$ and VIII $(0.309 \pm$ $0.0151 \mu \mathrm{m})$, whereas the minimum in stage I $(0.24 \pm 0.01$ $\mu \mathrm{m})$, with significant differences $(P<0.05)$ between these two variables.

The highest monthly egg contribution by embryonic stage was presented in July 2015 with 1,159,020 eggs (stage II and IV) and the lowest in October 2014 with 48,850 eggs (stage III) (Fig. 7).

The Pf-TL relationship in stage II with $\mathrm{R}^{2}=0.4288$ was the lowest coefficient of determination, and stage I was the highest with $\mathrm{R}^{2}=0.7827$ (Fig. 8). For the Pf-CL, the maximum coefficient values were recorded in stages I and IV $\left(R^{2}=0.516\right.$ and $R^{2}=0.512$, respectively), and the minimum in stage II with $R^{2}=0.2769$ (Fig. 8). 

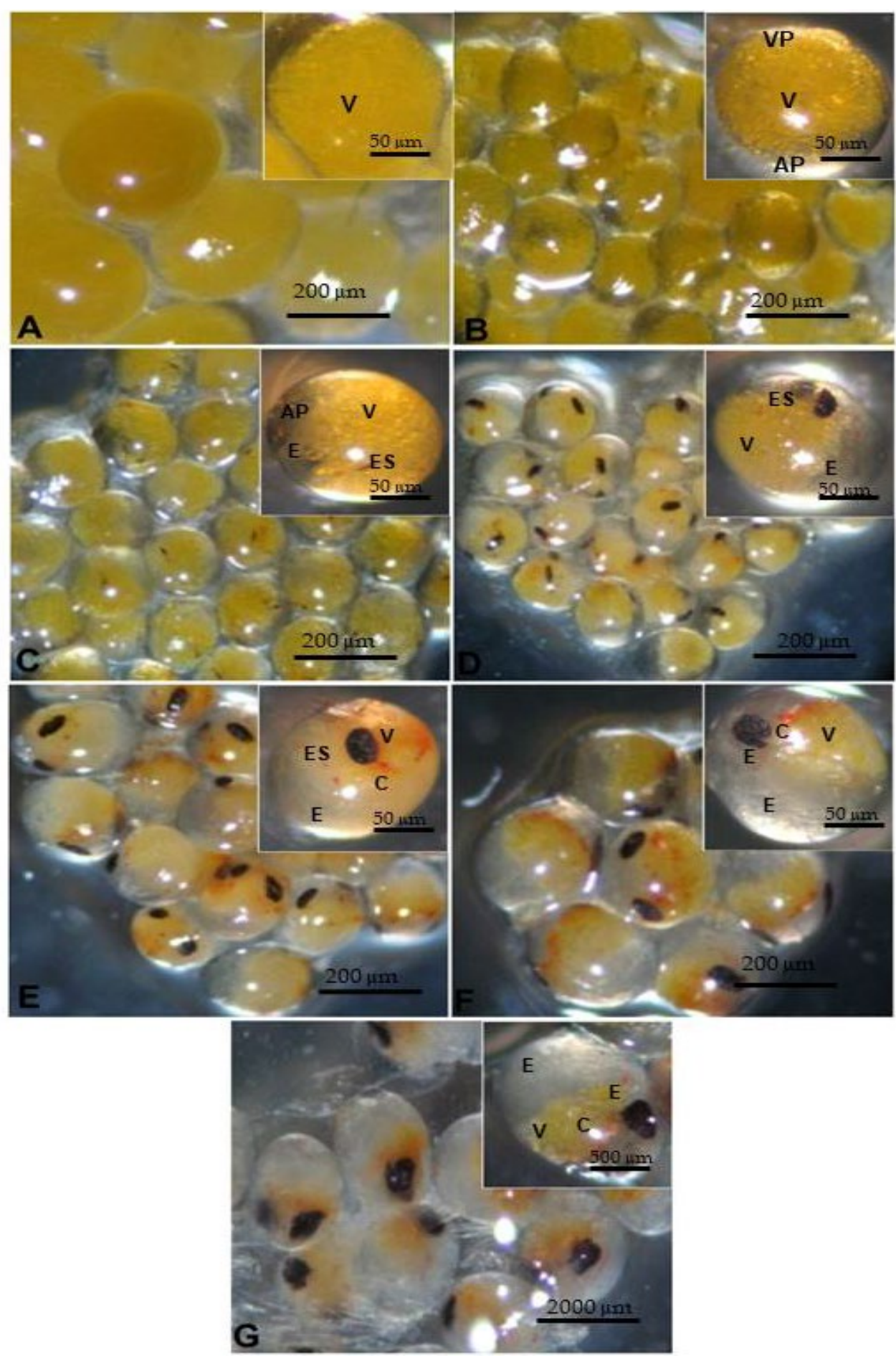

Fig 6. Stages of M. americanum embryonic development (scale $=500 \mu \mathrm{m}, 2 \mathrm{x}$ ). A. Stage I, B. Stage II, C. Stage III, D. Stage IV, E. Stage V, F. Stage VI, G. Stage VII. V: Vitelo, AP: Animal pole, VP: Vegetable pole, E: Embryo, C: Chromatophores, E: Eyes, ES: Eye spot 


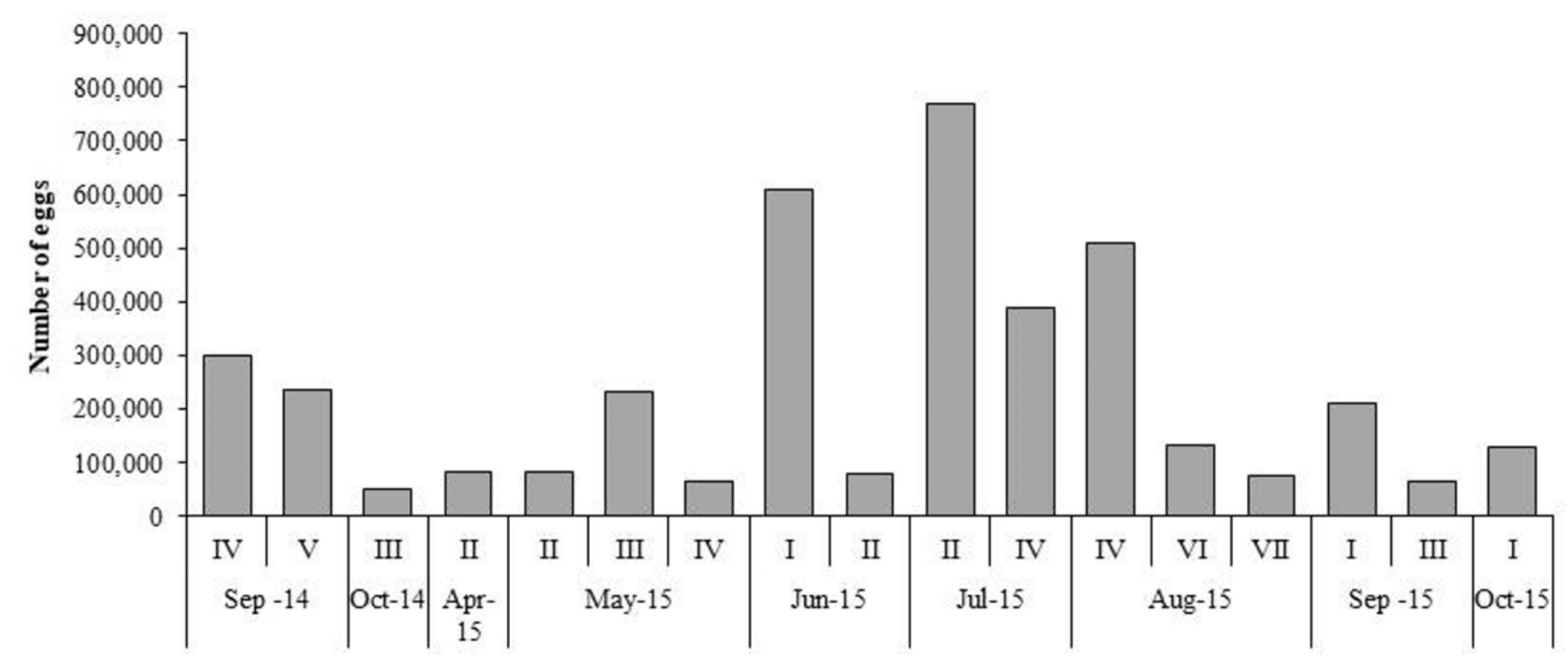

Fig 7. Number of eggs by stage of embryonic development of Macrobrachium americanum
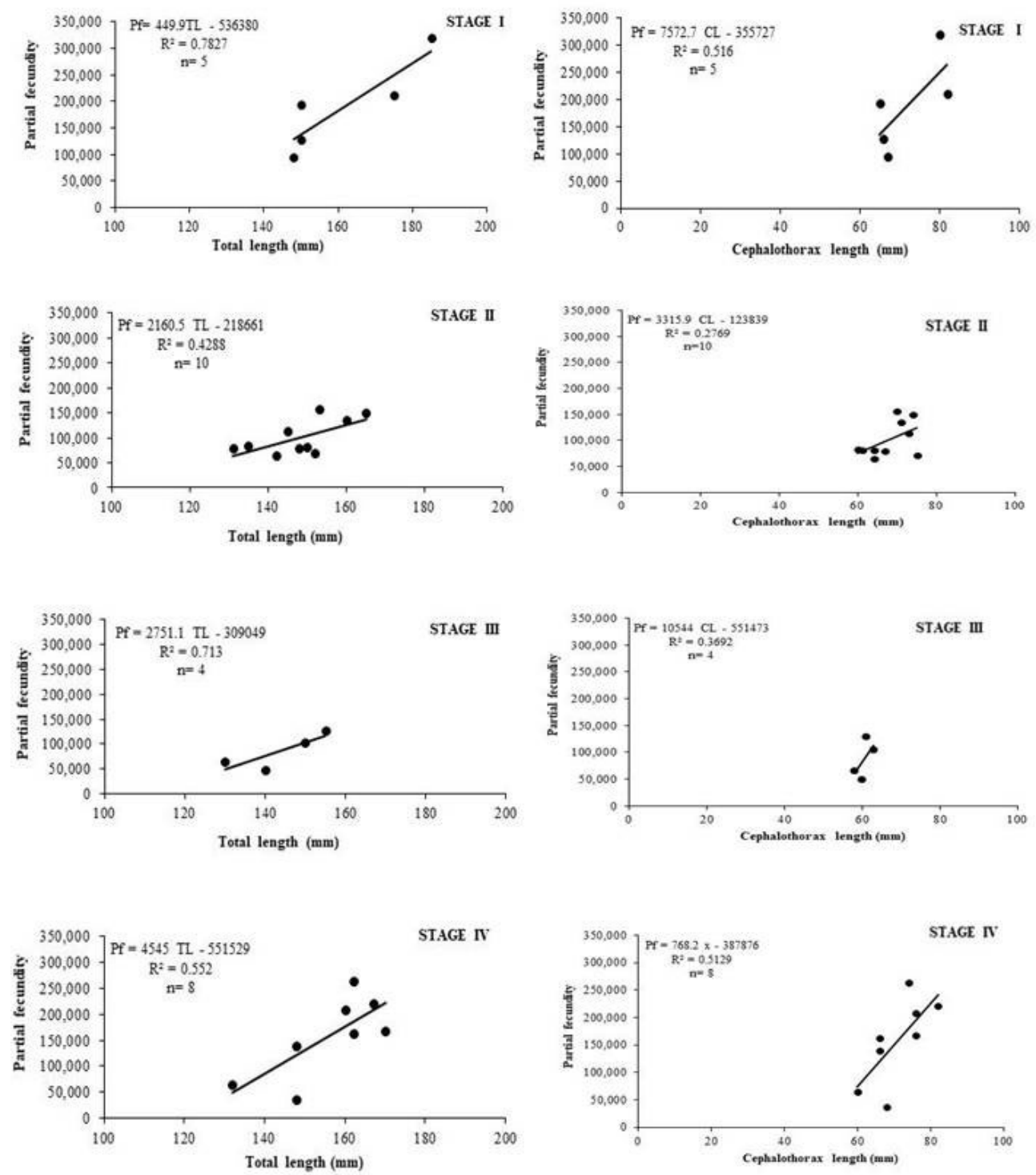

Fig 8. Fecundity partial relationship (Pf) - Total length (TL) and partial fecundity (Pf)- length of the cephalothorax (CL), considering the stage of embryonic development in Macrobrachium americanum 


\section{DISCUSSION}

The mouths of rivers and coastal lagoons play a fundamental role in the repopulation of species of the genus Macrobrachium in the upper and middle portions of rivers due to their amphidronic behavior (De los SantosRomero et al., 2006; McDowall, 2007; Villalobos-Hiriart et al., 2010). Juvenile organisms of the freshwater prawn $M$. americanum have been found in brackish waters as they stand salinity changes better than adults (Holttschmit and Pfeiler, 1984; Cifuentes-Lemus et al., 1990). The migrations seem to be related to the optimal salinity required by this species for the development of their eggs, the growth of larvae and juveniles, and their subsequent migration upstream up to more than $100 \mathrm{~km}$ (RodríguezDe la Cruz, 1967; Kensler et al., 1974; Velásquez-Orozco, 2005). In the present study, the capture of M. americanum took place in the middle part of the Petatlán River, being similar to what Villalobos-Hiriart et al. (2010) reported for the species captured in the middle and lower portions of the basins of the Copalita, Zimatán and Coyutla Rivers in Oaxaca, Mexico.

Little work has been done with $M$. americanum to describe aspects of the population. In the current study, organisms were presented in the size range of 85 to 230 $\mathrm{mm}$ in total length (Fig.1). In most of sampling months, larger organisms were observed in the intervals of 192 to $239 \mathrm{~mm}$ of TL, which coincides with what was reported by Pérez-Velázquez et al. (2006) for the same species in the Ameca River in the state of Nayarit, Mexico. However, size records differ from Puente-Gómez et al. (2006) for $M$. americanum who reported bigger sizes in females than in males in the state of Colima, Mexico. De los SantosRomero et al. (2006) reported the largest capture in the dry season for the Colotepec River estuary, Oaxaca as the largest organisms of $M$. americanum valued by local fishermen were recorded. Álvarez-Ruiz et al. (1996) reported that during the dry season (January to April) in Guanacaste, Costa Rica large organisms were captured in the high portions of the San Andrés River which were mostly males, while during the rainy season there were no big specimens. This does not coincide with the results of this study because the largest organisms were found in the rainy season (June to October, 2015).

The sex ratio can be referred to different growth stages (larval, juvenile or adult) or to different periods such as time of reproduction or migration. In the present study, the freshwater prawn $M$. americanum presented significant differences in the sex ratio $(0.39 \mathrm{~F}: 1 \mathrm{M})$; a higher presence of males was observed in most of the investigation period because females are protecting their eggs by staying in their shelters and therefore not being caught in traps in the middle part of the river, so this explains why the number of caught females was smaller during the sampling months. This could happen as $M$. americanum presents migratory habits as part of its reproductive behavior, according to the rainy period during the year, which determines an increase in the currents of rivers and streams. Individuals are dragged by these currents from the upper parts and are concentrated on the lower parts for reproduction, which could affect the sex ratio in certain areas. This coincides with the results for the same species ( $M$. americanum) in Guanacaste, Costa Rica where they managed to capture a higher proportion of males in the middle and upper portions of the river (Arana, 1974; Smitherman et al., 1974; Diarte-Plata et al., 2010, 2012). The study of fecundity in those populations with fishing potential is of particular interest, depending on their relationship with the capacity to renew them. In addition, it represents an important aspect of the knowledge of the reproductive strategy and the evolution of the population (García-Montes et al., 1987). In those species within the genus Macrobrachium, reproductive activity is defined as the time interval during which ovigerous females are found in a population (Williams, 1984; Cobo, 2000). The spawning process occurs about 6 to 20 hours after mating. During egg laying, the female's body is bent forward long enough to have close contact with the ventral portion of the thoracic region; eggs descend from the ovaries through the oviducts and are expelled by the genital pores at the base of the third pair of pereiopods to the incubation chamber, located between the fourth and first pair of pleopods. The eggs adhere to their bristles by means of an elastic membranous substance, where they are kept aerated by vigorous movements of the swim appendages (Coelho, 1981).

In $M$. americanum, the reproductive season is not yet well defined according to its distribution (Holthuis, 1954; Rodriguez-De la Cruz, 1968; Smitherman et al., 1974). Taking into account the presence of ovigerous females in the Petatlán River, $M$. americanum reproduces mainly between April and October, presenting a reproductive peak in July, which indicates a seasonal reproductive activity andalso coincides with the beginning of the rainy season. Valenti (1984) mentions that the species of the genus Macrobrachium have a continuous or seasonal reproduction with a long breeding season with some months of great reproductive activity (spawning). The existence of reproductive peaks in Macrobrachium is evident in the hottest season in temperate climates (Valenti et al., 1986). This behavior has been reported for species of the same genus, $M$. tenellum in the Ameca River, Jalisco-Nayarit, Mexico, with a reproductive peak between May and July (rainy season) with a seasonal reproductive pattern (Vargas-Ceballos, 2018); M. acanthurus presents reproductive activity throughout the year, with a peak from August to October (Williams, 1984).

According to Corey and Reid (1991) fecundity is a measure of a female's reproductive capacity and plays an important role within the freshwater prawn population, it is considered a measure of the reproductive ability of crustaceans and it is influenced by natural selection. In the present study, the fecundity range for M. americanum 
was 34554 to 342372 eggs, which is higher than the one reported by Gutiérrez-Jara (2010) for the same species. This author observed a fecundity between 17942 to 124 057, which was also higher than what has been reported for other species of the genus, as Mejía- Ortiz et al. (2001) reported for M. acanthurus (113 to 5568 eggs), Da Silva et al. (2004) for M. amazonicum (480 to 2, 128 eggs), Hattori et al. (2009) (16 to 1630 ) and Meireles et al. (2013) with an interval of 1341 to 2956 eggs and Lara and Wehrtman (2009) in M. carcinus (14 420 to 242437 eggs).

Fecundity is a reproductive aspect that depends, among other things, on the size of females since the physical abdominal space available to carry eggs is a limiting factor, as well as their physiological conditions (Da Silva et al., 2004; Parra et al., 2010). Connection between the female body size and the number of eggs is known from previous studies on freshwater crustaceans as in $M$. acanthurus (Anger and Moreira, 1998; Tamburus et al., 2012), $M$. amazonicum (Da Silva et al., 2004; Parra-Medina et al., 2008; Aya-Baquero and Velasco-Santamaria, 2013), $M$. carcinus (Graziani et al., 1993; Lara and Wehrtmann, 2009). In the present work, it was observed that the number of fertilized eggs varied considerably with total length. The length of ovigerous females of $M$. americanum captured for this study varied from 60 to $85 \mathrm{~mm}$, where the fecundity showed higher values (342 372 eggs) according to the increase in the total length of females $(180 \mathrm{~mm}$ of TL) and 62678 eggs in females with a shorter total length (Table 1). This may be due to the size that females present; the larger the size, the bigger the abdominal space. Ovigerous females of $M$. americanum are bigger than those seen for $M$. acanthurus in the Huitzilapan River, Veracruz, Mexico for ovigerous females with sizes of 42 to $110 \mathrm{~mm}$, as it happens with $M$. carcinus with a fecundity between 14420 to 242437 eggs, with ovigerous females that reached $220 \mathrm{~mm}$ in total length (Lobao et al., 1985; Camacho et al., 1997; Mejía-Ortiz et al., 2001; Lara and Wehrtmann, 2009). It has been reported that females of $M$. americanum can spawn, that is to carry adhered eggs, three or four times a year and produce more than 100 000 eggs each time, being generally the largest females (Arana, 1974).

The increase in the number of eggs appears to be related to body length (total length), as well as to the total weight of organisms. The relationship between female size and fecundity has been described through a linear regression, although in some cases the exponential or potential function can be used to describe this relationship (Hernáez and Palma, 2003). In the present study, the relationships $\mathrm{Pf}-\mathrm{TL}$ and $\mathrm{Pf}-\mathrm{CL}$ of $\mathrm{M}$. americanum were adjusted to a linear model, where the fecundity increases in a linear manner with the total length and the cephalothorax, explaining a fecundity variation of $55 \%$ with respect to $\mathrm{TL}$ and $\mathrm{CL}$ (Fig. $4 \mathrm{a}$ and b); these results are similar to those found by different authors as Gutiérrez-Jara (2010) for M. tenellum, M. acanthurus (Albertoni et al., 2002; Tamburus et al., 2012), M. amazonicum (Da Silva et al.,
2004; Lima et al., 2014), M. carcinus (Lobão et al., 1985; Lara and Wehrtmann, 2009 and M. olfersii (Mossolin and Bueno, 2002). With regards to the relationship between Pf-TW, the potential model was adjusted to describe the relationship where it is observed that the total weight of the female is significantly correlated with the number of eggs. It can be said that for $M$. americanum, as the female size and weight increases, the number of eggs also tends to increase. On the other hand, there was no association found between the Rf-TL, Rf-CL and Rf-TW of females since the correlation indexes were very low (Fig. 5a, b and c).

The number and size of eggs produced by a certain species may vary due to differences in the age and size of breeders (Ramalho et al., 2009; Freire et al., 2012; Lara et al, 2009). In this paper, embryonic stages for M. americanum were established based on the amount of vitelum and ocular pigmentation, as well as other characteristics such as the first appearance of appendages, which can be used as growth parameters for species of the family Palaemonidae (Yávar and Dupré, 2007; García-Guerrero and Hendrickx, 2009). During the days prior to the hatching of the embryos of $M$. americanum, they present all the characteristics of the state of Zoea I, which coincides with the same species mentioned by García-Guerrero and Hendrickx (2009), and with C. caementarius reported by Yávar and Dupré (2007) showing similar patterns of villi, abdomen proportion and cephalothorax, cephalic appendages and complex eyes.

The change of the spherical shape of the eggs during stage III into an elliptical form from stage IV observed in the present study has been reported as common in several palaemonid species, such as $M$. rosenbergii and M. acanthurus (García-Ulloa et al., 2004). Parra et al. (2010) report that as the length and width of the egg increase, the embryonic development advances, similar to what was observed in this study where the maximum egg diameter values of $M$. americanum were recorded in stage IV $(0.306 \pm 0.0147 \mu \mathrm{m})$ and VI $(0.309 \pm 0.0151$ $\mu \mathrm{m})$. However, the size of the eggs is bigger to what has been reported in females of $M$. amazonicum by Parra et al. (2010) who observed that the newly fertilized eggs measured $0.590 \mu \mathrm{m}$ in length and $0.460 \mu \mathrm{m}$ in width, and in a pre-hatching stage between $0.750 \mu \mathrm{m}$ and $0.510 \mu \mathrm{m}$, respectively.

This may also be due to the fact that in crustaceans the quantity of eggs held is limited by the space available under the abdomen; therefore, females contain a certain amount of embryos according to the shape and size of the eggs and their body size (Corey and Reid, 1991; Palma and Arana, 1997).

The fecundity is important for a species to maintain and increase the population density. It is also very important in estimating the reproductive potential of brood freshwater prawn which in turn helps management strategies of freshwater prawn hatcheries, estimating the number of spawners required for producing a desired quantity of seeds (Abdur Rashid et al., 2013). In the 
present study, the highest contribution of M. americanum eggs was observed in July 2015, in stages II and IV (Fig. 7). This coincides with Smitherman et al. (1974) where they observed that $M$. americanum reproduces most of the year, mainly in the rainy season between June and November. M. tenellum shows a similar behavior with a reproductive peak between June and December on the Mexican Pacific coasts (Cabrera et al., 1977; Román, 1979; Guzmán et al., 1982).

Analysis of the sex ratio, fecundity and description of the embryonic development can have innumerable advantages, such as promoting the recognition of embryos, improving the evaluation of the spawning site and studies related to the growth of the species in its natural environment; it is also important for the detection of changes in the population related to environmental factors, which can lead to a consequently lower productivity (Alekhnovich and Kulesh, 2001).

\section{ACKNOWLEDGMENTS}

The authors express their gratitude to the institutional support provided by COFFA and EDI from the Instituto Politécnico Nacional. Special thanks to Dr. Guerrero-Ruiz for translating this paper into English.

\section{ODNOS SPOLOVA, PLODNOST I MORFOMETRIJA JAJAŠCA SLATKOVODNE KOZICE Macrobrachium americanum (BATE, 1868) U RIJECI PETATLÁN, SINALOA, MEKSIKO}

\section{SAŽETAK}

Macrobrachium americanum ima visoku komercijalnu vrijednost $s$ dobrim mogućnostima ribolova i uzgoja u Meksiku. Trenutno postoji malo podataka o reproduktivnim aspektima navedene kozice pa se stoga u ovom radu analizirao omjer spolova, plodnost te morfometrija jajašaca $M$. americanum u rijeci Petatlán, Sinaloa, Meksiko. Omjer spolova je iznosio 0,39 F:1 M a uzorkovana je ukupno 31 jajonosna ženka. Djelomična plodnost je varirala od $34554-342372$ jajašca ( $P f \bar{x}=128$ $246 \pm 12306$ jajašaca).

Odnosi između duljine tijela i plodnosti $\left(R^{2}=0,5546\right)$, duljine cefalotoraksa i plodnosti $\left(R^{2}=0,4995\right)$ prilagođeni su linearnom modelu, a odnos ukupne mase i plodnosti potencijalnom modelu $\left(R^{2}=0,5013\right)$. Prosječna relativna plodnost iznosila je $37132 \pm 5162$ jaja/g. Ukupno je uočeno 7 faza embrionalnog razvoja. U prvim fazama jaje je imalo sferni, a u drugom jajasti oblik. Maksimalne vrijednosti promjera jaja prikazane su u fazama VII, VI i VIII. U fazi Il utvrdio se najveći broj jaja (1 013 073). Ključno je optimizirati eksploataciju populacije $M$. americanum prisutne u rijeci Petatlán stvaranjem znanstvenih osnova za održivost ribolova.
Ključne riječi: Embrionalni razvoj, jajosna ženka, razmnožavanje, slatkovodna kozica

\section{REFERENCES}

Abdur Rashid, M., Reza Md. S., Rowshan, A. B., 1, Mohammad, S. A., Zannatul, F., Mohammad, K. (2013): Fecundity and Embryonic Development in Three Macrobrachium Species. Journal of Entomology and Zoology Studies, 1(1), 3-11.

Albertoni, E.F., Palma-Silva, C., Esteves, F.A. (2002): Fecundity of Macrobrachium acanthurus Wiegmann, 1836 (Decapoda: Palaemonidae) in a tropical coastal lagoon subjected to human impacts (Macae, Brazil). Acta Limnologica Brasiliensia, 14(1), 71-80.

Alekhnovich, A.V., Kulesh, V. F. (2001): Variation in the Parameters of the Life Cycle in Prawns of the Genus Macrobrachium Bate (Crustacea: Palaemonidae). Russian Journal of Ecology, 32 (6), 420-424.

Álvarez-Ruiz, M. D., Cabrera Peña, J., Solano López, Y. (1996): Morfometría, época reproductiva y talla comercial de Macrobrachium americanum (Crustacea: Palaemonidae) en Guanacaste, Costa Rica. Revista de Biología Tropical, 44, 1, 127-132.

Anger, K., Moreira, G. (1998): Morphometric and reproductive traits of tropical caridean shrimps, Journal of Crustacean Biology, 18, 4, 823-838.

Aya-Baquero, E., Velasco-Santamaría, Y. (2013): Fecundidad y fertilidad de Macrobrachium amazonicum (Heller 1862) (Decapoda, Palaemonidae) del Piedemonte Llanero Colombiano, Revista de Medicina Veterinaria y Zooctenia de Córdoba, 18, 3, 3773-3780.

Arana, F. (1974): Experiencias sobre cultivo de langostino Macrobrachium americanum Bate en el Noroeste de México, México, D. F. 12.

Bauer, R. (2011a): Amphidromy and migrations of freshwater shrimps. In: A. Asakura (ed.). I. Costs, benefits evolutionary origins and an unusual case of amphidromy. New frontiers in crustacean biology. Proceedings of The Crustacean Society summer meeting, Tokyo, 20-24 September 2009, Brill, Leiden, 145-156.

Bauer, R. (2011b): Amphidromy and migrations of freshwater shrimps. In: A. Asakura (ed.). II. Delivery of hatching larvae to the sea, return of juvenile upstream migration and human impacts. New frontiers in crustacean biology. Proceedings of The Crustacean Society summer meeting, Tokyo, 20-24 September 2009, Brill, Leiden, 157-168.

Cabrera, 1., Chaves, J.C., Matínez, C. (1977): Fecundidad y cultivo de Macrobrachium tenellum (Smith, 1871) en el laboratorio. I Simposio Asociación Latinoamericana de Acuicultura. 10.

Camacho, M. E., Álvarez, F., Villalobos, J. L. (1997): Palaemonidae. In: E. González, R. Dirzo y R. Vogt (eds.). (Instituto de biología, Universidad Nacional Autónoma de México). Historia natural de los Tuxtlas, 411-414. 
Chirichigno, N., Fischer, W., Nauen, C. E. (1982): INFOPESCA. Catálogo de especies marinas de interés económico actual o potencial para América Latina, Parte 2. Pacífico central y suroriental FAO/PNUD. Roma. (SIC/82/2(212), $588 \mathrm{p}$.

Choy, C.S. (1985): A rapid method for removing and counting eggs from fresh and preserved decapod crustaceans. Aquaculture, 48, I, 364-372.

Cifuentes-Lemus, J.L., Torres-García, P., Frías, M. (1990): El océano y sus recursos. Vol. X. Pesquerías. FCE, México.

Cobo, V.J. (2002): Breeding period of the spider crab Mithraculus forceps (A. Milne Edwards) (Crustacea: Majidae: Mithracine) in the southeastern Brazilian coast, Revista Brasiliera de Biología, 19, 229-234.

Coelho, P. (1981): Cultivo de Camarones del Género Macrobrachium Bate (Decapoda, Palaemonidae) de Brasil. Brasil. 66.

Corey, D. M., Reid, S. (1991): The fecundity of thirtythree species of nine families of Caridean Shrimp: Comparative fecundity of decapod crustaceans. Crustaceana, 3(1), 27-60.

Da Silva, R. R., Sampaio, C. M. S., Santos, J. A. (2004): Fecundity and Fertility of Macrobrachium amazonicum (Crustacea: Palaemonidae). Journal Brazilian Biology, 64, 3a, 489-500.

De los Santos-Romero, R., Silva-Rivera, M. E., RuizVega, J. (2006): Distribución, producción biológica y aprovechamiento de especies de la familia Palaemonidae en los humedales de Colotepec, Oaxaca, México. Naturaleza y Desarrollo, 4, 1, 5-18.

Diarte-Plata, G., Sainz-Hernández, J. C., Aguiñaga-Cruz, J. A. (2010): Aspectos generales sobre la pesquería del camarón de río Macrobrachium americanum (Bate, 1868) en el norte de Sinaloa. VII Encuentro Nacional de Biotecnología del Instituto Politécnico Nacional. Mazatlán, Sinaloa, México.

Diarte-Plata, G., Escamilla-Montes, R., Granados-Alcantar, S., Sainz-Hernández, J. C., Arzola-González J. F. (2012): Capitulo V. Aspectos poblacionales del langostino de río Macrobrachium americanum (Bate, 1868). In: Recursos Naturales y Sistemas Productivos. R. Martínez-Ruiz, R. Félix-Gastélum, M. C. Martínez-Valenzuela y G. E. RojoMartínez (Eds.). 1 ${ }^{\text {a }}$ Edición. Universidad de Occidente Campus Los Mochis-Universidad Autónoma Indígena de México. Los Mochis, Ahome, Sinaloa, México.

Escamilla-Montes, R., De la Cruz-Agüero, G., Trinidad Villalejo-Fuerte, M., Diarte-Plata, G. (2013): Fecundidad de Callinectes arcuatus (Ordway, 1863) y C. bellicosus (Stimpson, 1859) (Decapoda: Brachyura: Portunidae) en la ensenada de La Paz, Golfo de California, México. Universidad y Ciencia, 9, 1, 53-61.

Espinosa-Chaurand, L. D., Vargas-Ceballos, M. A., GuzmánArroyo, M., Nolasco-Soria, H., Carrillo-Farnés, O., Chong-Carrillo, O., Vega-Villasante, F. (2011): Biología y cultivo de Macrobrachium tenellum: Estado del arte. Hidrobiológica, 21, 2, 99-117.

Freire, J.L., Marques, C.B., Silva, B.B. (2012): Estrutura populacional e biologia reprodutiva do camarão-daamazônia Macrobrachium amazonicum (Heller, 1862) (Decapoda: Palaemonidae) em um estuário da regiao nordeste do Pará, Brasil. Brazilian Journal of Aquatic Science and Technology, 16, 2, 65-76.

García-Guerrero, M.U., Hendrickx, M. (2009): External description of the embryonic development of the prawn, Macrobrachium americanum Bate, 1868 (Decapoda, Palaemonidae) based on the staging method. Crustaceana, 82, 11, 1413-1422.

García-Guerrero, M. (2010): Effect of temperature on consumption rate of main yolk components during the embryo development of the prawn Macrobrachium americanum (Crustacea: Decapoda: Palaemonidae). Journal World of Aquaculture Society, 41, 1, 84-92.

García-Montes, J. F., García, A., Soto, L. A. (1987): Morfometría, crecimiento relativo y fecundidad de la jaiba del Golfo Callinectes similis Williams, 1966 (Decapoda: Portunidae). Ciencias Marinas, 13, 4, 137161.

García-Ulloa, M., Rodríguez, H., Ogura, T. (2004): Calidad del huevecillo de dos especies de langostino (Palaemonidae) del género Macrobrachium ( $M$. rosenbergii, De Man 1879, y $M$. tenellum, Smith, 1871) variando la dieta de los reproductores: índices morfométricos. Avances en Investigación Agropecuaria. Revista de Investigación y difusión Científica, 1-8.

Goodyear, R., Martínez, V., Del Rosario, J. B. (1976): Moluscos y crustáceos decápodos del Rio Chiriquí. In: Biota de Panamá, Universidad de Panamá. http:// biota.wordpress.com/2008/04/25/los-peces-delrio-chiriqui-y-afluentes-principales/. Consulta 01/ VIII/2013.

Graziani, C., Chung, K., De Donato, M. (1993): Comportamiento reproductivo y fertilidad de Macrobrachium carcinus (Decapoda: Palaemonidae) en Venezuela. Revista de Biología Tropical, 41, 3, 657665.

Granados, B. A. A. (1980): Biología y aspectos poblacionales del langostino de río Macrobrachium americanum (Bate, 1868) (Decapoda: Palaemonidae) en algunas áreas de los estados de Michoacán y Guerrero. (Bachelor Thesis). Facultad de Ciencias. Universidad Nacional Autónoma de México, México, D. F., 120.

Gutiérrez-Jara, Y. (2010): Morfometría y reproducción de tres especies de langostinos de la vertiente del Pacífico de Costa Rica: Macrobrachium panamense, $M$. americanum y $M$. tenellum (Decapoda: Palaemonidae). (Bachelor Thesis). Universidad de Costa Rica, San José, 53.

Guzmán. A., M. Rojas, G. J., González, L. D, (1982): Ciclo anual de maduración y reproducci6n del "Chacal" Macrobrachium tenellum y su relación con los factores ambientales en las lagunas costeras de Midas y Tres Palos, Guerrero, México. (Decapoda: Palaemonidae). Anales del Instituto de Ciencias del Mar. y Limnolología, $9,67-80$ 
Guzmán, A. M. (1987): Biología, ecología y pesca del langostino Macrobrachium tenellum, en las lagunas costeras de Guerrero, México. (Bachelor Thesis). Centro de Ciencias del Mar y Limnología. Universidad Nacional Autónoma de México, México D. F. 70.

Hattori, G.Y., Barros, C.A., Barbosa, J.G.O., Magalhães, C. (2009): Fecundity of Macrobrachium amazonicum (Heller, 1862) (Crustacea, Decapoda, Palaemonidae) at medium Amazonas region, close to Itacoatiara (AM), Brazil. Anais do IX Congresso de Ecologia do Brasil, São Lourenço, 1, 1-3

Hernáez, P., Palma, S. (2003): Fecundidad, volumen del huevo y rendimiento reproductivo de cinco especies de porcelánidos intermareales del norte de Chile (Deca509 Macrobrachium tenellum reproductive biology (Decapoda, Porcellanidae). Investigaciones Marinas, Valparaíso. 31, 2, 35-46.

Hernández, L., Murugan, G., Ruiz-Campos, G., MaedaMartínez, A. M. (2007): Freshwater shrimp of the genus Macrobrachium (Decapoda: Palaemonidae) from the Baja California peninsula, Mexico. Journal of Crustacean Biology, 27, 2, 351-369.

Holthuis, L. B. (1954): On a collection of decapod Crustacea from the Republic of El Salvador (Central America). Leiden Zoologische Verhandelingen, 23, 1-43.

Holttschmit, K. H., Pfeiler, E. (1984): Effect of salinity on survival and development of larvae and postlarvae of Macrobrachium americanum Bate (Decapoda: Palaemonidae). Crustaceana, 46, 23-28.

Jayachandran, K.V. (2001): Palaemonid Prawns: Biodiversity, taxonomy, biology and Management. Science Publishers, 624.

Kensler, C. B., Weller de Restori, A., Grande Vidal, J. M. (1974): El desarrollo y cultivo del langostino de rio en Michoacán y Guerrero, México y pesquería de langosta en Michoacán, México. Contribución al estudio de las pesquerías en México. Programa de investigación y fomento pesqueros México /PNUD/FAO, 35 p. http:// www.fao.org/docrep/field/003/ac595s/ac595s00.htm, consulta 13.III.2013.

Lara, L. R., Wehrtmann I. S. (2009): Reproductive biology of the freshwater shrimp Macrobrachium carcinus (L.) (Decapoda: Palaemonidae) from Costa Rica, Central America. Journal of Crustacean Biology, 29, 3, 343-349.

Lima, J.F., Silva, L.M.A., Silva, T.C., Garcia,J.S., Pereira, I.S., Amaral, K.D.S. (2014): Reproductive aspects of Macrobrachium amazonicum (Decapoda: Palaemonidae) in the State of Amapá, Amazon River mouth. Acta Amazonica, 44, 2, 245-254.

Lobao, V. L., Valenti, W.C., Mello, J.T.C. (1985): Fecundidade em Macrobrachium carcinus (I.) do rio ribeira de Iguape. Bolletim do Instituto de Pesca, São Paulo, 12, 1-8.

Lohr, S. L. (1999): Muestreo: Diseño y Análisis. International Thompson Editores. México, D. F. 480.

McDowall, R. M. (2007): On amphidromy, a distinct form of diadromy in aquatic organisms. Fish and Fisheries,
8, 1-13.

Mejía-Ortiz, L. M., F. Álvarez, Román, R., Viccon-Pale, J. A. (2001): Fecundity and distribution of freshwater prawns of the genus Macrobrachium in the Huitzilapan River, Veracruz, México. Crustaceana, 74, 1, 69-77.

Meireles, A.L., Valenti, W.C., Mantelatto, F.L. (2013): Reproductive variability of the Amazon River prawn, Macrobrachium amazonicum (Caridea, Palaemonidae): influence of life cycle on egg production. Latin American Journal Aquatic Research, 41, 4, 718-731.

Mossolin, E.C., Bueno, S.L.S. (2002): Reproductive biology of Macrobrachium olfersi (Decapoda, Palaemonidae) in São Sebastião, Brazil. Journal Crustacean Biology, 22, 2, 367-376

Palma S., Arana, P. (1997): Aspectos reproductivos del langostino colorado (Pleuroncodes monodon $\mathrm{H}$. Milne Edwards, 1837) frente a la costa de Concepción, Chile. Investigaciones Marinas, 25, 203-221.

Parra, M. J.C., García, S.Y., Ferrer, A., Severeyn, H. (2010): Aspectos reproductivos del camarón Macrobrachium amazonicum (Heller) en la zona de Nazaret, San Rafael de El Mojón, Lago de Maracaibo, Venezuela. Ciencia, 16, 4, 402-408.

Pérez-Velázquez, P., Ulloa-Ramírez, P., Patiño-Valencia, J. L. (2006): Estado general de la pesquería comercial del camarón moya Macrobrachium tenellum de la región estuarina de Nayarit. III Foro Científico de Pesca Ribereña. SAGARPA-INP. Puerto Vallarta, Jalisco, 17-18.

Pineda-Barrera, J., Días de León, C.A.J., Uribe-Osorio, F. (1975): Fecundidad de la langosta roja Panulirus interruptus (Randall, 1842) en Baja California. Ciencia Pesquera, I, 99-118.

Ponce-Palafox, J. T., Arana-Magallón, F.C., CabanillasBeltrán, H., Esparza-Leal, H. (2002): Bases biológicas y técnicas para el cultivo de los camarones de agua dulce nativos del Pacífico Americano Macrobrachium tenellum (Smith, 1871) y M. americanum (Bate, 1968). CIVA 2002, 534-546. (http://www.civa2002.org)

Puente-Gómez, M., García-Boa, A., Ahumada-Aguayo, O., Zamorano-Acosta, C., Espino-Barr, E., Cabral-Solís, E. (2006): Análisis preliminar de los aspectos biológico pesqueros del recurso langostino Macrobrachium americanum en el estado de Colima. III Foro Científico de Pesca Ribereña. SAGARPA-INP. Puerto Vallarta, Jalisco, 91-92.

Ramalho, M.C., Valenti, W.C. (2009): Biology, fisheries and aquaculture of the Amazon River prawn Macrobrachium amazonicum: a review. Nauplius, 17, 2, 61-79.

Rodríguez-De la Cruz, M. C. (1967): II Palaemonidos del Atlántico y Vertiente Oriental de México con descripción de dos especies nuevas. Anales del instituto de Ciencias del Mar y Limnología. Anales del Instituto Nacional de Investigaciones Biológicas Pesqueras, 71-112.

Román, C.R. (1979): Contríbución al conocimiento de la biología y ecología de Mcrobrachium tenellum (Smith 1871) (Crustacea: Decpaoda: Palaemornidae). Anales del instituto de Ciencias del Mar y Limnología, 6, 1, 37- 
160.

SIIT, (2013): Sistema Integrado de Información Taxonómica. http://www.conabio.gob.mx/informacion/catalogo_ autoridades/doctos/siit.html. Consulta 01/II/2014.

Smitherman, R. O., Moss, D.D., Diaz, E. (1974): Observations on the Biology of Macrobrachium americanum Bate from a pond environment in Panamá. Journal World Aquaculture Society, 5, 29-40.

Tamburus, A.F., Mossolin, E.C., Mantelatto, F.L. (2012): Populational and reproductive aspects of Macrobrachium acanthurus (Wiegmann, 1836) (Crustacea: Palaemonidae) from north coast of São Paulo State, Brazil. Brazilian Journal of Aquatic Science and Technology, 16, 1, 9-18.

Valenti, W.C. (1984): Estudo populacional dos camarões de água doce Macrobrachium acanthurus (Wiegmann, 1836) e Macrobrachium carcinus (Linnaeus, 1758) do Rio Ribeira de Iguape (Crustacea, Palaemonidae). (Dissertação de Mestrado) São Paulo, Universidade de São Paulo. 149.

Valenti, W.C., Melo, J.T.C., Lobão, V.L. (1986): Dinâmica da reprodução de Macrobrachium acanthurus (Wiegmann, 1836) e Macrobrachium carcinus (Linnaeus, 1758) do Rio Ribeira de Iguape (Crustacea, Decapoda, Palaemonidae). Ciencia e Cultura, 38(7), 1256- 1262.

Vargas-Ceballos, M. A., López-Uriarte, E., GarcíaGuerrero, M. U., Vega-Villasante, F., Román-Contreras, R., Akintola, S. L., Chong-Carrillo, O. (2016): Infestation of Probopyrus pacificensis (Isopoda: Bopyridae) in Macrobrachium tenellum (Caridea: Palaemonidae) in the Ameca River, Jalisco, Mexico: prevalence and effects on growth. Pan-Am Journal Aquatic Science, 11, 1, 39-46.
Velázquez-Abunader, J. I., Villalejo-Fuerte, M., TrippQuezada, A. (2010): Fecundidad y proporción de sexos de Panulirus inflatus en la costa occidental del Golfo de California, México. Revista de Biología Marina y Oceanografía, 45, 1, 71-76.

Velásquez-Orozco, J. A. (2005): Estudio de etapas larvales, determinación de concentraciones de salinidad y alimento para la producción artificial de larvas de camarón de agua dulce Macrobrachium carcinus en Ixcán, Quiché. (Bachelor Thesis). Universidad de San Carlos de Guatemala. Guatemala, 77.

Villalobos-Hiriart, J. L., Álvarez, F., Hernández, C., De la Lanza-Espino, G., González-Mora, I. D. (2010): Crustáceos decápodos de las cuencas Copalita, Zimatán y Coyula, en Oaxaca, México. Revista Mexicana de Biodiversidad, 81, 99-111.

Williams, A. B. (1984): Shrimps, lobsters, and crabs of the Atlantic coast of the eastern United States, (Smithsonian Institution Press, Washington, D. C.). Maine to Florida, 1-550.

Yávar, C., Dupré, E. (2007): Desarrollo embrionario del camarón de río Cryphiops caementarius (Decapoda: Palaemonidae) en condiciones de laboratorio. Revista de Biología Tropical, 55, 15-24.

Zar, J. H. (2010): Biostatistical Analysis. Fifth Edition. Pearson Prentice Hall. Printed in New Jersey, United States of America, 947. 